\title{
Neotectonic activity and its geomorphic response in the Tangtse valley, Ladakh Himalaya
}

\author{
Vimal Singh \\ Wadia Institute of Himalayan Geology, 33 GMS Road, Dehra Dun-248001, Uttarakhand, INDIA, and Centre for Earth Sciences, Indian Institute of \\ Science, Bangalore-5600012, Karnataka, INDIA \\ E-mail:vimalgeo@gmail.com
}

The $800 \mathrm{~km}$ long dextral Karakorum fault bounding the southwestern margin of Tibet is commonly considered to be a discrete narrow fault zone. However, this fault is bifurcated between $33.5^{\circ} \mathrm{N}$ and $34.5^{\circ} \mathrm{N}$ into two parallel strands namely: the Pangong Tso and the Tangtse (Rutter et al. 2007). Slip rates inferred on the Karakorum fault ranges from 30-35 mm/yr to 3$4 \mathrm{~mm} / \mathrm{yr}$ (Molnar and Lyon-Caen 1989, Avouac and Tapponnier 1993, Liu et al. 1992, Liu, 1993, Searle et al. 1998 Tapponeir et al. 2001, Banerjee and Bürgmann 2002, Brown et al. 2002, Jade et al. 2004). Rutter et al. (2007) have shown evidences of shallow brittle deformation (such as clay-bearing gouges, cataclasite) along the Pangong strand but could not find comparable evidences along the Tangtse strand. Based on this observation, most recent slip is suggested to have been recorded only along the Pangong strand. However, preliminary data collected in this study from deformed fluvio-lacustrine Quaternary deposits cut by Tangtse strand suggest recent earthquake displacement to have occurred after $13 \mathrm{ka}$.

In Tangtse valley, fluvio-lacustrine Quaternary deposits are exposed for a length of $\sim 30 \mathrm{~km}$ along the Tangtse River. This thick sediment sequence, formed possibly due to damming of Tangste River, attains a thickness of up to $70 \mathrm{~m}$. Recent activity in Tangtse strand is expressed in the form of changed river course, deformed and displaced sediments, and development of fault gouge. Optically stimulated luminescence age of $\sim 13 \mathrm{ka}$ obtained from deformed lake sediments provides a firm lower bound, on the tectonic activity of Tangtse strand to after $\sim 13 \mathrm{ka}$. Tectonic activity at $\sim 50 \mathrm{ka}, \sim 35 \mathrm{ka}$, and $\sim 25 \mathrm{ka}$ has already been inferred from deformation seen at different levels in these type of deposits in adjacent valleys (Shyok Valley and Indus Valley near Leh) (Phartiyal et al. 2005). In the light of these new data, it is inferred that the Tangtse strand has been active during the past $\sim 15 \mathrm{ka}$.

\section{References}

Avouac JP and P Tapponnier. 1993. Kinematic model of active deformation in central Asia. Geophysical Research Letters 20: 895-898
Banerjee P and R Bürgmann. 2002. Convergence across the Northwest Himalaya from GPS measurement. Geophysical Research Letters 29(13): doi: 10.1029/2002GL015184

Brown ET, R Bendick, DL Bourlès, VK Gaur, P Molnar, GM Raisbeck and F Yiou. 2002. Slip rates of the Karakorum fault, Ladakh, India, determined using cosmic ray exposure dating of debris flows and moraines. Journal of Geophysical Research 107: doi: 10.1029/2000JB000100

Jade S, BC Bhatt, Z Yang, R Bendick, VK Gaur, P Molnar, MB Anand and D Kumar. 2004. GPS measurements from the Ladakh Himalaya, India: preliminary tests of plate-like or continuous deformation in Tibet. Geological Society of American Bulletin 116: 1385-1391

Liu Q. 1993. Paléoclimat et contraintes chronologiques sur les mouvements récent dans l'Ouest du Tibet: Failles du Karakorum et de Longmu Co-Gozha Co, lacs en pull-apart de Longmu Co et de Sumxi Co [Ph.D. dissertation]: Paris, Université Paris, v. VII. $358 \mathrm{p}$

Liu Q, JP Avouac, P Tapponnier and Q Zhang. 1992. Holocene movement along the southern part of the Karakorum fault: Abstracts, International Symposium on the Karakorum and Kunlun Mountains, June 5-9, 1992, Kashi [sic], China. $91 \mathrm{p}$

Molnar P and H Lyon-Caen. 1989. Fault plane solutions of earthquakes and active tectonics of the Tibetan Plateau and its margins. Geophysical Journal International 99: 123-153

Phartiyal B, A Sharma, R Upadhyay, Ram-Awatar and AK Sinha. 2005. Quaternary geology, tectonics and distribution of palaeo- and present fluvio/glacio lacustrine deposits in Ladakh, NW Indian Himalaya - a study based on field observations. Geomorphology 65. 241-256

Rutter EH, DR Faulkner, KH Brodie, RJ Phillips and MP Searle. 2007. Rock deformation processes in the Karakoram fault zone, Eastern Karakoram, Ladakh, NW India. Journal of Structural Geology 29: 1315-1326

Searle MP, RF Weinberg and WJ Dunlap. 1998. Transpressional tectonics along the Karakoram fault zone, northern Ladakh: constraints on Tibetan extrusion. In: Holdsworth RE, RA Strachan, JF Dewey. (Eds.). Continental Transpressional and Transtensional Tectonics. Geological Society of London, Special Publication 135: 307-326

Tapponnier P, ZQ Xu, F Roger, B Meyer, N Arnaud, G Wittlinger and JS Yang. 2001. Oblique stepwise rise and growth of the Tibet Plateau. Science 294: 1671-1677 